\title{
A Study on Electrolytic Tin-Nickel Alloy Plating from Fluoride Bath
}

\author{
R.D. SRivastava*, D. Tripathi* and R.C. MukerJeE*
}

\begin{abstract}
A study of the tin-nickel alloy plating from chloride-fluoride bath has been carried out and the effect of complexing the stannous ions with fluoride ions on polarization behaviour has been studied. Complexation of $\mathrm{Sn}$ (II) ions has been found to increase the extent of polarization and to shift the deposition potential of tin to a more negative value. Gradual addition of nickel chloride further shifted the cathode potential of the electrolyte indicating alloy deposition. Present observations indicated that for bright and smooth plating of alloy of equiatomic composition higher temperatures were needed. The best results were obtained at $65^{\circ} \mathrm{C}$ while below $45^{\circ} \mathrm{C}$ codeposition was not possible except at very low current densities.
\end{abstract}

\section{Introduction}

Since the introduction of bright tin-nickel electroplate from chloride-fluoride bath by Parkinson'), important advances have been made in the understanding and control of the deposition process. Cuthbertson and Parkinson ${ }^{2}$ worked out the conditions of codeposition of tin-nickel electroplate in detail and obtained bright alloy plating from a solution containing tin (II) and nickel (II) chloride along with sodium fluoride and ammonium bifluoride. Davies $^{3}$ modified the bath by replacing sodium fluoride by ammonium fluoride to avoid the continuous slow precipitation of sodium hexafluoro-stannate (VI) formed by aerial oxidation. Lowenheim and Gores) introduced fluoride as ammonium bifluoride in the electrolyte to obtain excellent solderable deposits. Conditions of codeposition of tin and nickel were studied by Serravale $^{5}$ from conductometric and potentiometric titrations. The process of electroplating tin-nickel alloy from fluoride bath and the properties of the deposit have been further studied by Kudryavtsev et al. ${ }^{6)(11)}$ and Dunkic ${ }^{12,13)}$.

Deposits obtained from chloride-fluoride bath containing $65-68 \%$ tin were shown to be a single phase, intermetallic compounds, with hexa-

* Chemical Laboratories, University of Lucknow (Lucknow-226007 India) gonal nickel arsenide unit cell by Rooksby ${ }^{14}$. The intermetallic compound was shown to decompose in expected stable phases, viz., $\mathrm{Ni}_{3} \mathrm{Sn}_{2}$ and $\mathrm{Ni}_{3} \mathrm{Sn}_{4}$ above $350^{\circ} \mathrm{C}$. Further studies on the structure of the deposit carried by Smart and Robins $^{15}$ ) and Clarke ${ }^{18}$ ) have confirmed the deposition of the alloy in equiatomic proportion to produce metastable phase of the intermetallic compound NiSn.

Electrodeposited tin-nickel alloy film is known to be highly corrosion resistant over a wide range of $\mathrm{pH}^{17}$, 18).

The present work describes a systematic investigation of the process of codeposition of tin-nickel alloy from a chloride-fluoride bath. The effect of such parameters as polarization, temperature and current density, has been undertaken to obtain a suitable bath for the codeposition of the alloy in equiatomic proportions.

\section{Experimental}

The electrolysis was accomplished in a rectangular cell made of $0.30 \mathrm{~cm}$ thick perspex sheet. The interelectrode distance was maintained at $15 \mathrm{~cm}$. A copper strip $(2 \times 10 \mathrm{~cm})$ was pasted on a perspex plate with the help of an acid proof, heat resistant (to the extent of $100^{\circ} \mathrm{C}$ and non-conducting) adhesive, so as to make it cathode. The free surface of the copper strip 
was cleaned with nitric acid, washed with distilled water before using as cathode. Only $10 \mathrm{~cm}^{2}$ area of the cathode was immersed in the electrolyte. The rest of the surface of cathode above the meniscus of the electrolyte was covered with the adhesive. The copper cathode was electroplated at the desired current density until the whole of the surface of copper cathode was covered with the desired electrodeposit and a stationary cathode potential was reached. Cathode potentials at constant current densities were measured using Luggin's capillary with fine tip placed in contact with the cathode and other end immersed in a saturated $\mathrm{KCl}$ solution of the calomel half cell. The electrolytic cell was immersed in a thermostat to provide temperature control. Current and potential measurements were made as outlined ${ }^{19)}$ previously. The anodes used were of material depending on the electrolyte concerned and are mentioned with the results of the appropriate experiments. All chemicals used were Analar (B.D.H. grade).

In order to determine the composition of the deposit the electroplate was made on a smooth and bright stainless steel cathode. The deposit was peeled off and a known weight of it was dissolved in concentrated $\mathrm{HCl}$. Tin was precipitated by concentrated $\mathrm{HNO}_{3}$ as metastannic acid which was strongly heated to give tin dioxide. Tin was thus analysed. Nickel in the filtrate was analysed gravimetrically by the dimethylglyoxime method.

\section{Results and Discussion}

Standard potentials of the processes $\mathrm{Ni}^{2+}+$ $2 \mathrm{e}^{-}=\mathrm{Ni}$, and $\mathrm{Sn}^{2+}+2 \mathrm{e}^{-}=\mathrm{Sn}$ are $-0.25 \mathrm{~V}$ and $-0.136 \mathrm{~V}$ respectively. Although the difference in the discharge potentials of tin and nickel ions was very small, a satisfactory deposit consisting of a single phase bright plate could not be obtained from a simple mixture of tin and nickel chloride. Addition of fluoride ions to the electrolyte helped to bring the discharge potentials of the two ions closer together to enable the codeposition of the alloy.

The variation of cathode potential with addition of fluoride ions in the form of ammonium fluoride in the electrolyte containing $50 \mathrm{~g} / 1$ of $\mathrm{SnCl}_{2} \cdot 2 \mathrm{H}_{2} \mathrm{O}$ has been summarized in Table 1 and shown in Fig. 1. The gradual addition of

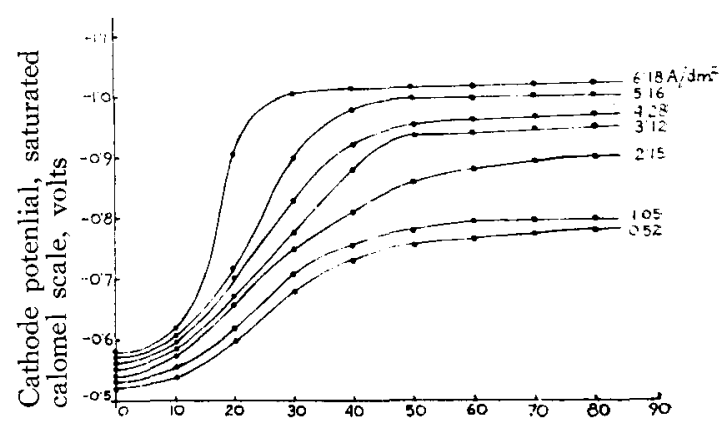

Amount of $\mathrm{NH}_{4} \mathrm{~F}, \mathrm{~g} / 1$

Fig. 1 Variation of cathode potential with the addition of $\mathrm{NH}_{4} \mathrm{~F}$ in $\mathrm{SnCl}_{2} \cdot 2 \mathrm{H}_{2} \mathrm{O}$ electrolyte

Table 1 Variation of cathode potential with the addition of ammonium fluoride in $\operatorname{Tin}($ III) chloride

\begin{tabular}{c|r|r|r|r|r|r|r}
\hline \hline $\begin{array}{l}\text { Plating current } \\
\text { density A/ } \mathrm{dm}^{2}\end{array}$ & 0.52 & 1.05 & 2.15 & 3.12 & 4.28 & 5.16 & 6.18 \\
\hline $\begin{array}{l}\text { Amount of ammo- } \\
\text { nium fluoride g/l }\end{array}$ & \multicolumn{7}{|c|}{ Cathode potential on saturated calomel scale, volts } \\
\hline 0 & -0.522 & -0.532 & -0.540 & -0.552 & -0.564 & -0.568 & -0.576 \\
10 & -0.538 & -0.554 & -0.572 & -0.584 & -0.592 & -0.602 & -0.614 \\
20 & -0.596 & -0.616 & -0.658 & -0.670 & -0.706 & -0.712 & -0.906 \\
30 & -0.680 & -0.708 & -0.746 & -0.772 & -0.826 & -0.895 & -1.005 \\
40 & -0.726 & -0.748 & -0.806 & -0.875 & -0.918 & -0.956 & -1.010 \\
50 & -0.752 & -0.770 & -0.858 & -0.932 & -0.948 & -0.992 & -1.014 \\
60 & -0.759 & -0.782 & -0.874 & -0.940 & -0.960 & -0.994 & -1.016 \\
70 & -0.774 & -0.794 & -0.892 & -0.942 & -0.966 & -0.996 & -1.018 \\
80 & -0.780 & -0.798 & -0.901 & -0.944 & -0.968 & -0.998 & -1.020 \\
\hline
\end{tabular}

Electrolyte : $50 \mathrm{~g} / 1 \mathrm{SnCl}_{2} \cdot 2 \mathrm{H}_{2} \mathrm{O}$ Anode used : Tin, Temp. : $65^{\circ} \mathrm{C}$ 
ammonium fluoride to the solution of $\operatorname{tin}$ (II) chloride at a constant temperature of $65^{\circ} \mathrm{C}$, shifted the cathode potential towards a more negative valus for each value of current densities from 0.52 to $6.18 \mathrm{~A} / \mathrm{dm}^{2}$. The change in cathode potential was slow up to $16 \mathrm{~g} / 1$ of ammonium fluoride followed by a rapid shift up to $33 \mathrm{~g} / 1$ and finally a practically constant value of cathode potential was attained after addition of more than $50 \mathrm{~g} / 1$ of ammonium fluoride. It can thus be inferred from the above observations that at a given current density $\mathrm{Sn}^{2+}$ ions are at first converted into ionic compornd $\mathrm{SnF}_{2}$, and on further addition of fluoride ions, complex ions $\mathrm{Sn}_{2} \mathrm{~F}_{5}{ }^{-}, \mathrm{SnF}_{3}{ }^{-}$and $\mathrm{SnF}_{4}{ }^{2-}$ are formed. The amount of ammonium fluoride required for complete conversion of $\mathrm{Sn}^{2+}$ into $\mathrm{SnF}_{4}{ }^{2-}$ ions in a solution containing $50 \mathrm{~g} / \mathrm{l}$ of $\mathrm{SnCl}_{2} \cdot 2 \mathrm{H}_{2} \mathrm{O}$ has been calculated to be $32.75 \mathrm{~g}$. As practically all the $\mathrm{Sn}^{2+}$ ions are converted into complex ions their equilibrium concentration in the electrolyte is diminished so as to give a rapid shift in cathode potential towards a more electronegative value. This behaviour became more appreciable as the current density increased (c.f. the curve at c.d. $6.18 \mathrm{~A} / \mathrm{dm}^{2}$ ).

Further addition of ammonium fluoride beyond $33 \mathrm{~g} / \mathrm{l}$ resulted in a slow increase in potential which can be due to slow aerial oxidation of $\mathrm{Sn}$ (II) to $\mathrm{Sn}$ (IV) resulting in the formation of the complex ions $\mathrm{SnF}_{6}{ }^{2-3}$. As the formation of hexafluoro-stannate from tetrafluoro-stannite ions does not result in further decrease in free $\mathrm{Sn}^{2+}$, the change in cathode potential to a more ne- gative value possibly appears to be due to much lower value of the dissociation constant of $\mathrm{SnF}_{6}{ }^{2-}$ ions. Further addition of ammonium fluoride beyond $50 \mathrm{~g} / 1$ resulted in giving a practically constant value of cathode potential. This indicated that the equilibrium of the reaction $\mathrm{SnF}_{1}{ }^{2-}$ $+2 \mathrm{~F}^{-}=\mathrm{SnF}_{6}{ }^{2-}+2 \mathrm{e}^{-}$has been attained.

Schaap ${ }^{20)}$ has shown the existance of $\mathrm{SnF}_{3}{ }^{-}$ ions in acidic or neutral solution of $\mathrm{Sn}^{2+}$ electrolyte from polarographic studies. According to them extremely lower values of dissociation constant of the latter ion was responsible for further shift in cathode potential when all the $\mathrm{Sn}^{2+}$ were completely complexed.

Variation of cathode potential during codeposition of the tin and nickel from a solution

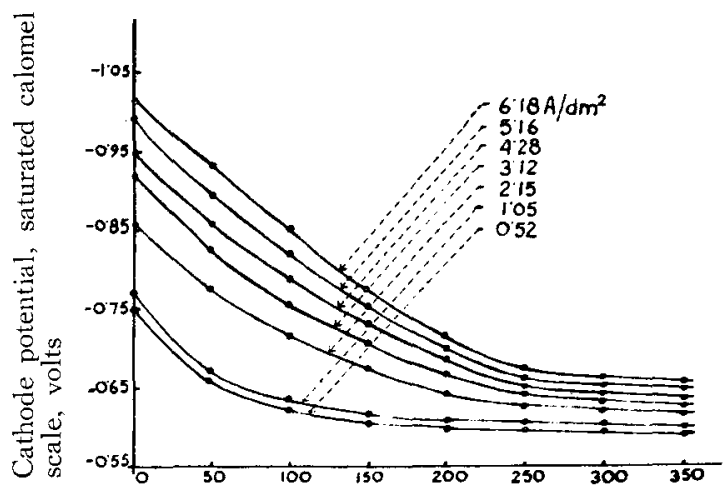

Amount of $\mathrm{NiCl}_{2} \cdot 6 \mathrm{H}_{2} \mathrm{O}, \mathrm{g} / l$

Fig. 2 Variation of cathode potential with the addition of $\mathrm{NiCl}_{2} \cdot 6 \mathrm{H}_{2} \mathrm{O}$ in the electrolyte containing $50 \mathrm{~g} / \mathrm{l}$ of $\mathrm{SnCl}_{2}$. $2 \mathrm{H}_{2} \mathrm{O}$

Table 2 Variation of cathode potential with the addition of nickel chloride

\begin{tabular}{|c|c|c|c|c|c|c|c|}
\hline $\begin{array}{l}\text { Plating } \\
\text { current } \\
\text { density } \\
\mathrm{A} / \mathrm{dm}^{2}\end{array}$ & 0.52 & 1.05 & 2.15 & 3.12 & 4.28 & 5.16 & 6.18 \\
\hline \multicolumn{3}{|c|}{$\begin{array}{l}\text { Amount of } \mathrm{NiCl}_{2} \cdot 6 \mathrm{H}_{2} \mathrm{O} \\
\text { added, } \mathrm{g} / \mathrm{l}\end{array}$} & \multicolumn{5}{|c|}{$\begin{array}{l}\text { Cathode potential on saturated calomel } \\
\text { scale, volts. }\end{array}$} \\
\hline 0 & -0.752 & -0.770 & -0.858 & -0.922 & -0.948 & -0.992 & -1.014 \\
\hline 50 & -0.656 & -0.671 & -0.773 & -0.825 & -0.859 & -0.895 & -0.933 \\
\hline 100 & -0.621 & -0.634 & -0.716 & -0.754 & -0.787 & -0.820 & -0.852 \\
\hline 150 & -0.606 & -0.617 & -0.674 & -0.706 & -0.730 & -0.752 & -0.772 \\
\hline 200 & -0.598 & -0.606 & -0.639 & -0.666 & -0.686 & -0.698 & -0.714 \\
\hline 250 & -0.595 & -0.603 & -0.625 & -0.642 & -0.651 & -0.663 & -0.672 \\
\hline 300 & -0.593 & -0.601 & -0.618 & -0.633 & -0.642 & -0.652 & -0.663 \\
\hline 350 & -0.590 & -0.598 & -0.614 & -0.625 & -0.637 & -0.644 & -0.652 \\
\hline
\end{tabular}

Electrolyte : $50 \mathrm{~g} / 1 \mathrm{SnCl}_{2} \cdot 2 \mathrm{H}_{2} \mathrm{O}+50 \mathrm{~g} / 1 \mathrm{NH}_{4} \mathrm{~F}$, Anode : tin-nickel alloy, Temp. : $65^{\circ} \mathrm{C}$ 
Table 3 Effect of nickel concentration on the percentage of electrodeposit

\begin{tabular}{|c|c|c|c|c|}
\hline $\begin{array}{l}\text { Plating current } \\
\text { density } \mathrm{A} / \mathrm{dm}^{2}\end{array}$ & 0.50 & 1.50 & 2.50 & 4.00 \\
\hline \multicolumn{2}{|c|}{$\begin{array}{l}\text { Amount of } \mathrm{NiCl}_{2} \cdot 6 \mathrm{H}_{2} \mathrm{O} \\
\text { added, } \mathrm{g} / \mathrm{l}\end{array}$} & \multicolumn{3}{|c|}{$\begin{array}{l}\text { Nickel percentage in } \\
\text { the alloy }\end{array}$} \\
\hline 100 & 31.1 & 27.5 & 24.7 & 24.3 \\
\hline 150 & 33.2 & 29.9 & 27.9 & 27.7 \\
\hline 200 & 34.2 & 33.4 & 31.5 & 30.8 \\
\hline 250 & 36.2 & 34.8 & 32.8 & 31.8 \\
\hline 300 & 36.7 & 35.2 & 34.3 & 33.7 \\
\hline 350 & 36.9 & 35.3 & 36.2 & 34.9 \\
\hline 400 & 37.2 & 35.3 & 36.2 & 36.5 \\
\hline
\end{tabular}

Electrolyte : $50 \mathrm{~g} / 1 \mathrm{SnCl}_{2} \cdot 2 \mathrm{H}_{2} \mathrm{O}+50 \mathrm{~g} / 1 \quad \mathrm{NH}_{4} \mathrm{~F}$ containing $50 \mathrm{~g} / \mathrm{l}$ of $\mathrm{SnCl}_{2} \cdot 2 \mathrm{H}_{2} \mathrm{O}$ and $50 \mathrm{~g} / \mathrm{l}$ of $\mathrm{NH}_{4} \mathrm{~F}$ with the gradual addition of $\mathrm{NiCl}_{2} \cdot 6 \mathrm{H}_{2} \mathrm{O}$ has been recorded in Table 2 and depicted in Fig. 2. The shift towards less negative values of cathode potential was observed at constant current densities. The decrease in polarization became more pronounced at low current densities in comparison at high current densities.

The analysis of the electrodeposits obtained on a stainless steel plate from a bath containing $50 \mathrm{~g} / 1 \mathrm{SnCl}_{2} \cdot 2 \mathrm{H}_{2} \mathrm{O}, 50 \mathrm{~g} / 1 \mathrm{NH}_{4} \mathrm{~F}$ with varying amount of $\mathrm{NiCl}_{2} \cdot 6 \mathrm{H}_{2} \mathrm{O}$ at various current densities revealed that bright deposits containing tin and nickel in approximately equiatomic ratio were obtained with bath containing $200-300 \mathrm{~g} / 1$ of $\mathrm{NiCl}_{2} \cdot 6 \mathrm{H}_{2} \mathrm{O}$ (Table 3). The nickel content, however, was found to increase with:

(1) increasing the current density,

(2) increasing the bath temperature,

(3) increasing the ratio $\mathrm{Ni}^{2+} / \mathrm{Sn}^{2+}$ and $\mathrm{F}^{-} /$
$\mathrm{Sn}^{2+}$

(4) decreasing the bath $\mathrm{pH}$ by adding $\mathrm{HF}$ or $\mathrm{HCl}$,

and

(5) increasing the chloride concentration by adding $\mathrm{HCl}$.

Deposits obtained from a bath containing $\mathrm{NH}_{4} \mathrm{~F}$ were found to be bright, brittle and porous while those with $\mathrm{NaF}$ were matt but elastic. When fluoride was added as $\mathrm{NH}_{4} \mathrm{HF}_{2}$, matt, porous and brittle deposits were obtained. With $\mathrm{KF}$ matt deposits were obtained. When fluoride of both the ions $\mathrm{NH}_{4}{ }^{+}$and $\mathrm{Na}^{+}$were present in the electrolyte the deposits obtained were quite bright, smooth, without cracks and less porous. This indicated that $\mathrm{Na}^{+*}$ ions play an important role in bright tin-nickel alloy plating which may be introduced either as sodium fluoride or sodium chloride.

As a result of the investigations made so far the following baths are recommended for the most satisfactory tin-nickel alloy electroplate:

\begin{tabular}{lrlr}
\hline \multicolumn{1}{c}{$\mathrm{A}$} & \multicolumn{2}{c}{$\mathrm{B}$} \\
$\mathrm{SnCl}_{2} \cdot 2 \mathrm{H}_{2}$ & $50 \mathrm{~g} / 1$ & $\mathrm{SnCl}_{2} \cdot 2 \mathrm{H}_{2} \mathrm{O}$ & $50 \mathrm{~g} / 1$ \\
$\mathrm{NiCl}_{2} \cdot 6 \mathrm{H}_{2} \mathrm{O}$ & $250 \mathrm{~g} / 1$ & $\mathrm{NiCl}_{2} \cdot 6 \mathrm{H}_{2} \mathrm{O}$ & $250 \mathrm{~g} / 1$ \\
$\mathrm{NH}_{4} \mathrm{~F}$ & $50 \mathrm{~g} / 1$ & $\mathrm{NH}_{4} \mathrm{~F}$ & $35 \mathrm{~g} / 1$ \\
$\mathrm{NaCl}$ & $40 \mathrm{~g} / 1$ & $\mathrm{NaF}$ & $30 \mathrm{~g} / 1$ \\
c.d. $\quad 0.5-4.0 \mathrm{~A} / \mathrm{dm}^{2}$ & c.d. $0.5-4.0 \mathrm{~A} / \mathrm{dm}^{2}$ \\
Temperature & $65^{\circ} \mathrm{C}$ & Temperature & $65^{\circ} \mathrm{C}$ \\
Sufficient $\mathrm{HCl}$ & & Sufficient $\mathrm{HCl}$ \\
to make pH & 2.5 & to make pH & 2.5 \\
\hline
\end{tabular}

These baths were found to be stable for a pretty long time and may be successfully employed for commercial tin-nickel alloy plating on copper or brass materials. Stirring of the bath

Table 4 Variation of cathode potential with temperature in tin-nickel alloy blating solution

\begin{tabular}{|c|c|c|c|c|c|c|}
\hline $\begin{array}{l}\text { Plating current } \\
\text { density } \mathrm{A} / \mathrm{dm}^{2}\end{array}$ & 0.50 & 1.03 & 2.05 & 3.04 & 4.06 & 5.02 \\
\hline $\begin{array}{l}\text { Plating solution } \\
\text { Temperature }{ }^{\circ} \mathrm{C}\end{array}$ & \multicolumn{6}{|c|}{ Cathode potential on saturated calomel scale, volts. } \\
\hline 20 & -0.712 & -0.722 & -0.761 & -0.777 & -0.792 & -0.803 \\
\hline 30 & -0.633 & -0.684 & -0.734 & -0.746 & -0.771 & -0.788 \\
\hline 40 & -0.633 & -0.647 & -0.696 & -0.723 & -0.748 & -0.769 \\
\hline 50 & -0.603 & -0.614 & -0.652 & -0.677 & -0.686 & -0.704 \\
\hline 60 & -0.598 & -0.608 & -0.633 & -0.652 & -0.662 & -0.678 \\
\hline 70 & -0.592 & -0.598 & -0.616 & -0.633 & -0.640 & -0.646 \\
\hline 80 & -0.588 & -0.592 & -0.598 & -0.611 & -0.615 & -0.620 \\
\hline
\end{tabular}

Electrolyte : $50 \mathrm{~g} / \mathrm{l} \mathrm{SnCl}{ }_{2} \cdot 2 \mathrm{H}_{2} \mathrm{O}+250 \mathrm{~g} / \mathrm{NiCl}_{2} \cdot 6 \mathrm{H}_{2} \mathrm{O}+50 \mathrm{~g} / 1 \quad \mathrm{NH}_{4} \mathrm{~F}, \mathrm{pH}=2.5$ 


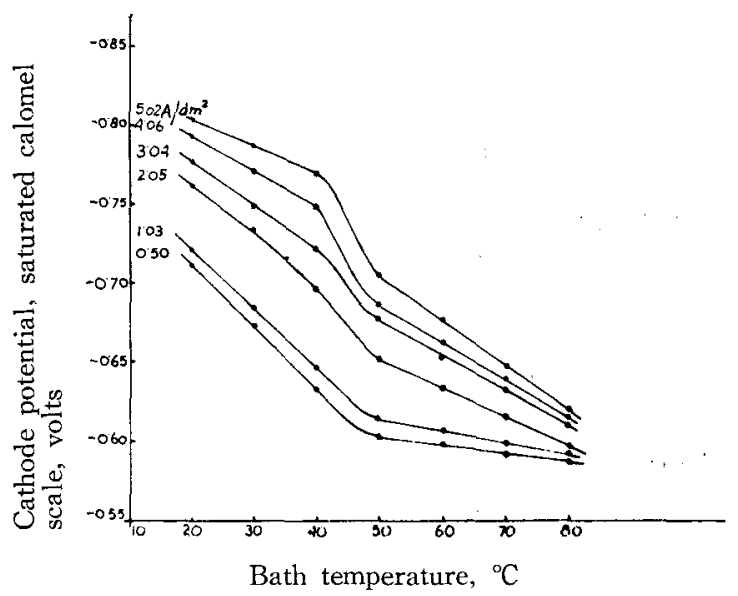

Fig. 3 Variation of cathode potential with temperature in tin-nickel alloy plating solution

was found to give the best results in so far as the brightness of the coatings were concerned, as it inhibited the deposition of some black material on the electroplate.

The effect of temperature on cathode potential of $\mathrm{Ni}-\mathrm{Sn}$ electrolyte at constant current density has been recorded in Table 4 and shown in Fig. 3. It has been observed that the increase in temperature decreased the extent of polarization linearly up to a temperature of $40^{\circ} \mathrm{C}$ followed by a remarkable fall in the temperature range of $40-50^{\circ} \mathrm{C}$. After $50^{\circ} \mathrm{C}$ the decrease in polarization was again linear but was not marked. From the analysis of the electrodeposited alloys it has been observed that codeposition was only possible at temperatures aaove $50^{\circ} \mathrm{C}$ and the best results were obtained at $65^{\circ} \mathrm{C}$. At lower temperature tin alone was found to deposit except at very low current densities when the deposits were dull in appearance.

\section{Summary}

A study of the tin nickel alloy plating from chloridefluoride bath has been carried out and the effect of complexing the $\mathrm{Sn}^{2+}$ ions with fluoride ions on polarization behaviour has been studied. Complexation of $\mathrm{Sn}^{2+}$ ions has been found to increase the extent of polarization and to shift the deposition potential of tin to a more negative value. Gradual addition of nickel chloride further shifted the cathode potential of the electrolyte indicating alloy deposition. Present observations indicated that for bright and smooth plating of $\mathrm{Sn}-\mathrm{Ni}$ alloy of equiatomic composition higher tmperatures were needed. The best results were obtained at $65^{\circ} \mathrm{C}$ while below $45^{\circ} \mathrm{C}$ codeposition was not possible except at very low current densities.

\section{Acknowledgement :}

Grateful acknowledgement is made to the State Council of Scientific and Industrial Research, U.P. for the award of a Junior Research Fellowhip to one of us (R.C.M.).

$<$ E 450 $>$ (Received Dec. 3, 1975)

\section{References;}

1) N. Parkinson, J. Electrodepositor's Tech. Soc. 27, 129 (1951).

2) J.W. Cuthbertson, N. Parkinson, H.P. Rooksby, J. Electrochem. Soc. 100, 107 (1953).

3) A.E. Davies, Trans. Inst. Met. Finishing 31, 401 (1954).

4) R.T. Gore, F.A. Lowenheim, Iron Age. 177, 59 (1956).

5) G. Serravale, Met. Ital. 49, 99 (1957).

6) K.M. Tyutina, N.T. Kudryavtsev, Doklady Akad. Nauk. USSR 115, 530 (1957).

7) K.M. Tyutina, N.T. Kudryavtsev, Zhur. Priklad. Khim. 31, 1054 (1958).

8) N.T. Kudryavtsev, K.M. Tyutina, Manik. Doklady Vysshei Shkvly, Khim. Tekhnol. 3, 435 (1958).

9) N.T. Kudryavtsev, K.M. Tyntina, L.V. Kosmodamianskaya, Zashchita Metal. 2, 467 (1966).

10) N.T. Kudryavtsev, K.M. Tyutina, L.V. Kosmodamianskaya, M.M. Yarlykov, ibid. 3, 198 (1967).

11) N.T. Kudryavtsev, K.M. Tyutina, L.V. Kosmodamianskaya, USSR. Pat. 310951 (1971); Chem. Abst. 75, 147197 b (1971).

12) Gojko Dunkic, Technika (Belgrade) 22, 2132(1968).

13) Gojko Dunkic, ibid. 23, 330, (1969).

14) H.P. Rooksby, J. Electrodepositor's Tech. Soc. 27, 153 (1951).

15) R.F. Smart, D.A. Robins, Trans. Inst. Met. Finishing 37, 108 (1960).

16) P.K. Dutta, M. Clarke, ibid. 46, 20 (1968).

17) M. Clarke, R.G.P. Flbourne, Electrochim. Acta 16, 1949 (1971).

18) M. Ckarke, R.G.P. Elbourne, Corrosion Science 8, 29 (1968).

19) R.D. Srivastava, S. Kumar, Acta Chim. Hung. 78, 139 (1973).

20) W.B. Schaap, J.A. Davis, W.H. Nobergall, $J$. Amer. Chem. Soc. 76, 5226 (1954). 